\title{
Coping Strategies and Household Food Security in Drought-Prone Areas in Ethiopia: The Case of Lay Gayint District
}

\author{
Arega Bazezew Berlie \\ Department of Geography and Environmental Studies \\ Bahir Dar University, Ethiopia \\ Email: bazezewarega@yahoo.com \\ DOI//http://dx.doi.org/10.4314/gjdsv12i1\&2.1
}

\begin{abstract}
A range of factors from physical environmental circumstances to policy and institutions-related issues affect households' involvement in long-term strategies for positive livelihood outcomes. The general objective of this study was to examine households' response to undesirable situations for food security outcomes. Questionnaire, in-depth interview and focus group discussions were the major data collection techniques. A major finding is that despite the low level of productivity related to local environmental constraints, adaptation strategies were not in a position to improve the livelihoods of the poor in the study area. The study found out that, planting trees for the market, livestock diversification and natural resource conservation were vital adaptive strategies employed by the better-off households. Short-term responses to meet the shortfall of consumption needs, such as selling charcoal and fuel wood, taking loans/credits and borrowing in kind or cash from friends were the major ex-post coping strategies practised by the poor and vulnerable households. In drought-prone areas such as Lay Gayint district, a serious problem for agricultural production is scarcity and irregularity of rainfall. Thus, there is the need to adapt early maturing and drought-resistant varieties, efficient use of available water and the growing of highland apple trees and planting Eucalyptus trees in accessible areas for better livelihoods.
\end{abstract}

Keywords: Agro-ecology, Livelihood diversification, Water harvesting, Lay Gayint, Ethiopia

\section{INTRODUCTION}

Chronic food insecurity and/or vulnerability to food insecurity arising from high population pressure, land degradation and drought are a defining problem in the study area that affects thousands of poor rural households, especially from the 1970s onwards. Continuous out-migration, hunger and/or food shortage, illiteracy, conflict on resources, incapability to purchase inputs, poor asset endowments are some of the indicators of 
chronic food insecurity in the study area. These poor households are residing in rural areas in which rain-fed agriculture is the major livelihood. Due to continuous cultivation for centuries and poor land management practices as well as unpredictable rainfall, the agricultural activities are not able to feed the growing population let alone savings. As a result, a considerable number of poor households are dependent on food aid, making the district one of the largest beneficiaries of the government safety net programmes for more than a decade. A continuous receiving of food transfer has developed dependency syndrome, which is a good manifestation of the district. The insufficiency and ineffectiveness of the programme means that households in drought-prone areas such as Lay Gayint have to practise some form of coping and adaptive strategies for subsistence and to bring positive food security outcomes in the long run.

Scholars such as Webb and Braun (1994) and Wisner, Blaikie, Cannon and Davis (2003) stated that poor people are not passive receivers of undesirable situations; they employ several strategies to make ease of the situations. People who die during famine/starvation could not be seen as passive victims but losers of a hard struggle for survival. Therefore, when hazards or undesirable conditions happened, people try to cope with and not rely much on outsiders, unless and otherwise everything becomes out of their control (Heijmens, 2001). Writers such as Webb and Braun (1994), Dietz and von der Geest (2004), Querish, (2007) and Patrice (1993) pointed out that coping strategies represent a set of activities that are undertaken in a particular sequence of actions by a household in response to shocks, which include famine, drought and other calamities. Adaptation on the other hand, is related to long-term strategies and helps to improve food availability and access through their own production and income diversification It also anticipates events of shocks in advance (Mahrijan \& Chhetri, 2006; Ellis, 2003). This makes adaptation to be a novel concept in the field of climate change (Smit \& Wandel, 2006). This showed that minimizing risk is not always an option; rather adaptation strategies using multiple livelihoods should be a choice for poor households who are susceptible to climate related shocks.

Few studies (Degefa, 2005; Deressa, Hassan, Tekie, Mahmud \& Ringler, 2008; Markos, 1997; Webb \& Braun, 1994) in relation to coping and adaptive strategies have been documented in Ethiopia. However, none of them compared coping and adaption strategies and many of the works that have been done are either regional or national level. More importantly, no study has been done in the study area in relation to coping and adaptation strategies at household level.

Therefore, the present study fills an important knowledge gap. It also proposes alternative solutions for policy issues by focusing on drought-prone and impoverished district - Lay Gayint district, where households' mitigation strategies for better food security outcomes are poorly developed. The general objective of the study was to assess the factors affecting households' participation in long-term strategies for the improvements of livelihoods. The specific objectives include: (i) To identify the severity 
of food insecurity using coping strategy index (ii) To examine the situations of coping and adaptive strategies between wealth categories and agro-ecological zones.

\section{METHODOLOGY}

\section{Description of the Study Area}

The study was carried out in Lay Gayint district in the Amhara Region (Fig. 1). Lay Gayint covers a total area of $1320.3 \mathrm{~km}^{2}$ and has a population density of 185 persons per $\mathrm{km}^{2}$ (CSA, 2010). It is one of the densely populated districts in the Region. The topography is rugged with elevations varying between $1200 \mathrm{~m}$ to above $4000 \mathrm{~m}$ above sea level. The area receives annual rainfall of $898.3 \mathrm{~mm}$. June, July and August are the rainy months. The mean annual temperature ranges from $4^{\circ} \mathrm{C}$ (on top of Guna Mountains) to $28^{\circ} \mathrm{C}$ (at the bottom of the Tekeze river valley).

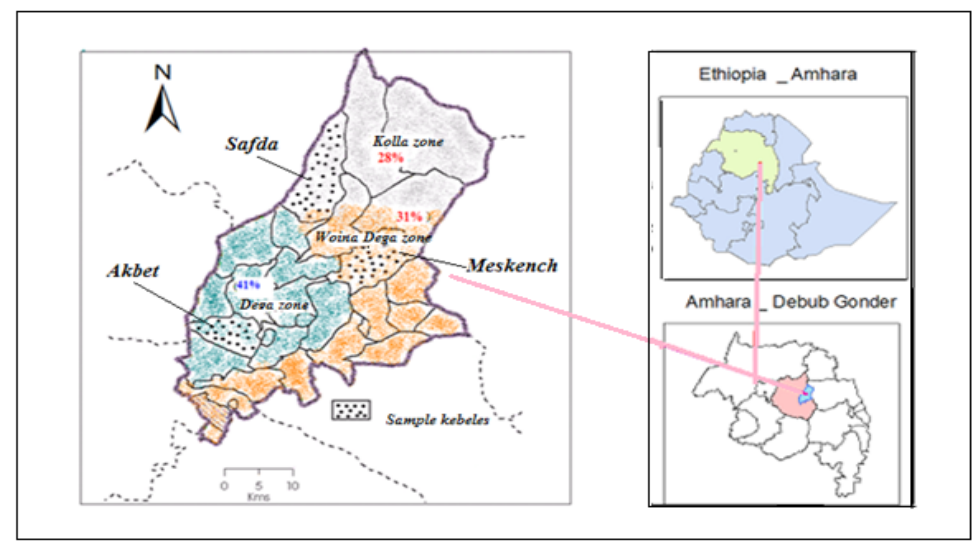

Figure1 - Location map of Lay Gayint district in South Gondar Administrative Zone of ANRS

Black and red (Cambisols) soils, black (Vertisols) soils and Leptosols soils are the dominant soil types in the district (Akliluet al., 2000). Based on the traditional agro-ecological classification, three agro-climatic zones are found in the area: Dega (cool), Woina-Dega (temperate) and Kolla (hot tropical). Small scale mixed agriculture is the dominant source of livelihood to the local people.

\section{Sampling, Data Collection and Analysis}

The study employed purposive, cluster and simple random sampling methods to select specific sample sites and households. Selection of the study district was purposive based on the researcher's prior knowledge of the area. The specific rural kebele administrations (RKAs) (the lowest tiers in the administrative 
structure of the country) were selected in a cluster sampling approach, where all the RKAs in the district were first clustered into three major agro-ecological zones - Kolla, lowland; Woina-Dega, mid-highland and Dega, highland, with respective elevations of 500-1500, 1500-2300 and above $2300 \mathrm{~m}$ above sea level. Households in each RKA were further grouped into wealth categories based on the information obtained from focus group discussions (FGDs), key informants (KIs), authors' prior experience and secondary sources.

It was assumed that the same risk/shock has different impact on households in different wealth groups. A total of 201 households were selected for a questionnaire survey from the three RKAs, using proportional stratified random sampling technique based on the sampling frames obtained from the RKA offices. In addition to the household survey, a total of six key informant interviews and three focus group discussions were conducted in each of the three RKAs. This is due to the fact that mixed research approach minimizes some of the limitations of using single method because quantitative or qualitative research methods are not sufficient to address the complex social phenomena when they are treated independently.

The questionnaire was prepared on major issues such as coping strategies, long-term strategies (water harvesting, livelihood diversification, land management practices and growing of highland apple trees and Eucalyptus trees in mitigating climate-related shocks, perception of droughts and food security/insecurity status of the households). In-depth interview and focus group discussions were held on issues such as coping and adaptive strategies and households' vulnerability to food insecurity. The data generated by the structured questionnaire were entered into the Statistical Package for Social Scientists version 20 and were analyzed using descriptive statistics such as frequencies, tables and percentages as well as coping strategy index. Data collected through in-depth interview, FGDs, life history narratives and direct observations were documented and analyzed textually to substantiate the statistical results from the structured questionnaire.

In analyzing the quantitative data, descriptive statistics and coping strategy index were used. The basic idea of coping strategy index is to measure the frequency and the severity of household's food security status (Maxwell, 2008). According to Hoddinott (1999), it is used to identify how much food shortage is a serious problem in the study area. In the selection of coping strategy index, three main points underpin its validity: the list of the right coping strategies, the frequency of the specific strategies in the recent past and the severity of each strategy considered by individuals. Taking into account Maxwell (2008) and Hondiott (1999) coping strategy index and from the author's experience, all the strategies were weighted against their severity and frequency of occurrences. Accordingly, reducing the quantity of meals, consume less preferred food, migrate to search job were weighted as one. Reduce the number of meals, consume seed reserve, harvesting immature crops and sale of livestock were weighted as two and others such as skip food throughout the day, eating wild/famine foods, selling productive assets such as land were weighted as three. Likewise, "often is" counted as four, "from time to time" is counted as 
three, "rarely" is counted as two and "never" is counted as one. The higher the weighted sum of the coping strategy index, the higher the level of household food insecurity.

\section{RESULTS AND DISCUSSION}

\section{Coping and Adaptive Strategies: Household Level Analysis}

The agricultural activity in the study area is characterized by low level of technology, low crop production and risky subsistence. Even in the modest harvesting years, the use of production enhancing technologies and crop production were extremely low. In addition, there are severe constraints in the livestock sector in general and draught animals in particular. These prevailing conditions forced the poor households to engage in shortterm (coping) and long-term (adaptive) strategies to climate and climate-related shocks to maintain the food security status of their households. Dietz and von der Geest (2004) indicated that coping strategies are the bundle of producer responses to the decline of food availability and entitlements in abnormal seasons, while adaptive strategies involve a permanent change in the mix of ways in which food is acquired, irrespective of the year in question. Thus, adaptation strategies are more of planned and anticipated, while coping strategies are usually spontaneous and have greater damage to the natural environment. Sampled households in the study area employed both coping and adaptive strategies in the face of wide variety of risks through their labour, capability and resources to relieve the challenges. Thus, the discussions focused on the coping and adaptation strategies employed by the sampled households during food crises and climate change situations.

\section{Coping Strategies of Households}

Poor people are not submissive to unexpected shocks; they design strategies to tackle unusual, abnormal or adverse situations for food self-sufficiency. Sources such as Webb and Braun (1994) and Wisner, Blaikie, Cannon and Davis (2003) indicated that food insecure households consciously follow well-defined sequence of coping strategies from less flexible to more harmful to the environment. For the present study, the summary of Lobell and Burke (2010), Patrice (1993) and Wondowsen (2011) coping strategy models was employed. The survey results showed that reducing the quantity of meals $(69 \%)$, postpone special festivals ( $78 \%)$, selling small ruminants (64\%), harvesting immature food crops (58\%), selling big livestock to buy food (54\%) were the major coping strategies employed by the respondents (see Table 1). Reducing the frequency of meals, request neighbors or relatives for gifts/loans, and minimize expenditure on schools and medication are reversible and are not erosive. Damaging or erosive coping strategies such as out-migration of the entire families, selling farm implements and begging were practised more in the Kolla zone, indicating that coping strategies are exhausted in this agro-ecology. It was also learnt from key informants that Kolla is the most vulnerable part of the district to food insecurity. Previous study (Guinand, 2001), for example, revealed that in the Simien massif part of the Tekeze lowland) coping mechanisms were limited to 
the sale of livestock and out-migration of the whole family. Likewise, Markos (1997), in a study conducted in drought-prone areas of Northern Ethiopia, listed the major coping strategies such as reducing consumption (83\%), relief assistance (82.3\%), and livestock sale (69.2\%).

The findings revealed that the sampled households in the study area employ ample coping strategies but the tactics used differ from one household to the other based partly on the resources at their disposal. For instance, the findings revealed that short-term strategies (coping) were more vital for the poor and female-headed households than the better-off households. As it was shown in Table 1, selling of big livestock, which could be taken as the major depleting of productive assets, was common in Woina-Dega zone. For example, Silvestri, Bryan, Ringler, Herrero and Okoba (2012) showed that selling of livestock is an important strategy for poor households to cope with climate-related shocks.

Table 1: Households' coping strategies (percentage of respondents)

\begin{tabular}{|l|l|l|l|l|}
\hline Coping strategy & Dega & Woina-Dega & Kolla & Total \\
\hline Reducing the quantity of meals & 81.4 & 71.4 & 44.3 & 69.0 \\
\hline Reducing the numbers and types of meals & 8.2 & 65.7 & 77.1 & 52.0 \\
\hline Postpone special festivals & 67 & 78 & 89 & 78 \\
\hline Selling small ruminants & 75.7 & 75.7 & 36.1 & 64.0 \\
\hline Selling charcoal and fuel wood & 22.9 & 42.9 & 36.1 & 34.0 \\
\hline Harvesting immature food crops & 82.9 & 52.9 & 36.1 & 58.0 \\
\hline Selling big livestock to buy food & 54.3 & 75.7 & 27.9 & 54.0 \\
\hline Consuming seed reserves & 52.9 & 54.3 & 37.7 & 49.0 \\
\hline Selling farm implements & 18 & 23 & 36 & 25.6 \\
\hline Out-migration of family members & 51.4 & 30.0 & 61.0 & 47.0 \\
\hline Going without food throughout the day & 54.3 & 31.4 & 11.5 & 33.0 \\
\hline Selling land to purchase food & 14.3 & 25.7 & 47.5 & 28.0 \\
\hline Consuming wild foods & 40.0 & 28.6 & 9.8 & 27.0 \\
\hline Begging & 7.1 & 1.4 & 21.3 & 9.0 \\
\hline
\end{tabular}

Source: Field survey, March 2011

In-depth interview with key informants and focus group discussion participants indicated that households commonly employed reducing meals, selling small ruminants and selling non-productive assets during mild periods. If the severity of food shortage increases, 
households start selling big ruminants such as cows and farm oxen. This showed that during food crises, the basic asset for the poor households was livestock, especially small and big ruminants. A key informant from Woina-Dega zone narrated his experiences as follows:

Animals ranging from small to big are vital for survival. They are used as traction power, source of milk and butter and sources of cash at times of food crises. Last year, my family was in food crises. I was having a considerable number of small ruminants such as goats and sheep and I sold some of them and purchased food and seed crops. Now, I am left with only two sheep, one ox, one donkey and three chickens (Key Informant [KI] interview, March 20, 2011).

The continuous selling of productive assets such as livestock, land and farm oxen is an indication of depleting tangible assets. This is likely to expose such households to chronic food insecurity. The Key informants interviewed indicated that the repeated failure of rainfall has exhausted the coping options of the farm households in their localities, making them fall back on the consumption of seed reserves and sale of farm implements for survival. About $95 \%$ of the total households contend that the continuous use of coping strategies has resulted in depletion of assets and led to chronic food insecurity. In relation to this, a key informant from the Dega agro-ecological zone shared his experience in the following ways:

Because of the failure of spring rain and delay of summer rain in 2009/10 crop year, my family faced food shortage. I have seven family members and two of them were high school students in 2011 academic year. To overcome the food crises and to educate my children, I sold the only milking cow that I have and in the next year I sold the only ox I owned and now, I am left with considerable numbers of apple trees, one calf and two sheep. If the spring rain becomes scanty or summer rain delays, my family will starve. The problem is severe because I am not a member of the safety-net programme, though I satisfy the criteria to become a beneficiary of the safety-net programme (KI, March 20, 2011).

\section{Regenerative Strategies}

In Table 2, the sampled households employed petty trading, causal labor, participating in safety net programs (cash or food for work), and taking part in the resettlement programme from degraded, drought-prone and densely populated areas to fertile and moisture reliable regions to regenerate livelihoods. Among the regenerative strategies mentioned, significant number of households was beneficiary of the productive safetynet programme (56\%) in which Kolla is the highest beneficiary among others. 
Arega Bazezew Berlie

CopingStrategiesandHouseholdFoodSecurityinDrought-ProneAreasinEthiopia:TheCaseofLayGayintDistrict

Table 2: Regenerative strategies (percentage of respondents)

\begin{tabular}{|l|l|l|l|l|}
\hline & Dega & Woina-Dega & Kolla & Total \\
\hline Engaging in casual labor & 41.4 & 31.4 & 37.7 & 37.0 \\
\hline Engaging in petty trade & 28.6 & 28.6 & 24.1 & 27.1 \\
\hline Changing coping into adaptive strategies & 18.0 & 12.0 & 14.8 & 14.9 \\
\hline Engaging in safety-net program & 38.6 & 55.7 & 75.4 & 56.0 \\
\hline Voluntary resettlement program & 10.0 & 36.0 & 28.0 & 24.0 \\
\hline
\end{tabular}

Source: Field survey, March 2011

From the informants' opinion, it was learnt that in drought-prone areas where natural resources are exhausted/degraded, coping strategies alone could not improve chronic food insecurity; hence, the need for productive safety-net programme and other food security programmes such as voluntary resettlement and integrated extension package programmes as a regenerative strategies. Though resettlement as a regenerative strategy was not important in all agro-ecological zones, Woina-Dega and Kolla zones account for the highest share.

This shows that the two zones are the most food insecure and the highest beneficiaries of governments' safety-net programme. In all agro-ecological zones, the changing of short-term strategies into long-term strategies was very low, indicating that they are intertwined with poverty and food insecurity. In Table 2, one can see that the recovering strategies were low, indicating that poverty is deep in the study area.

\section{Coping Strategy Index}

From the different coping strategies households employ during food crises, 10 strategies commonly practised by the sampled households were selected for the calculation of CSI. As shown in Table 3, the highest weight sum was calculated for harvesting immature food crops (474), selling of livestock to purchase food (416) and reducing the number of meals (210). According to the phases of coping strategies that had been studied by Patrice (1993), majority of the households were grouped to the second phase of coping strategies. Patrice classified this second phase of coping strategies as absorbing risk. From the findings, majority of the households are into absorbing risk. This means most of them passed the stage of minimizing risk such as livelihood diversification, engaging in social support networks, moving short distance to search employment opportunities and consume less preferred food. According to the key informants and food security experts' opinion, food insecurity is a chronic problem in that the average, households in the study area consume from own production for only about six months. The food security expert added that for the rest of the months households survive through governments' safety-net programmes, 
borrowing cash or food from relatives and/or neighbors, reducing meals and engaging in daily labor (if there are opportunities).

Table 3: Coping strategy index of the households

\begin{tabular}{|l|l|l|l|l|l|}
\hline Coping Strategy & Often & $\begin{array}{l}\text { Time } \\
\text { to time }\end{array}$ & Rarely & Never & $\begin{array}{l}\text { Weighted } \\
\text { sum }\end{array}$ \\
\hline Without food throughout the day & 33 & 141 & 21 & 6 & 201 \\
\hline Consuming wild foods & - & - & 150 & 12 & 162 \\
\hline Selling land to purchase food & - & 21 & 30 & 120 & 171 \\
\hline Reducing the number of meals & 180 & 20 & 10 & - & 210 \\
\hline Consuming seed reserves & 32 & 90 & 86 & - & 208 \\
\hline Harvesting immature food crops & 400 & 60 & 14 & - & 474 \\
\hline Selling livestock to buy food & 320 & 80 & 16 & - & 416 \\
\hline Reducing the quantity of meals & 101 & 30 & 7 & - & 138 \\
\hline Consuming less preferred food & 120 & 5 & - & - & 125 \\
\hline Migrating to search job & 71 & 21 & 2 & - & 94 \\
\hline
\end{tabular}

Note - Total is not $100 \%$ because of multiple responses

Households' responses, key informants opinion and information from food security experts revealed that households in the study area are living at the edge and any small push makes them vulnerable to food insecurity. In relation to this, Ellis (2003) indicated that living on the edge evokes the sense of small push or sending a person over the edge results in great calamity in human welfare and just smooth or harsh of this knife/ edge that determines the household's ability to survive or thrive. Therefore, before the households complete their vital assets for coping strategies; long-term strategies should be explored to move them out of food insecurity and destitution in a sustained manner.

\section{Adaptation Strategies of the Households}

Adaptation is a long-term strategy of averting a threat with consistent responses. In the study area, local level adaptation strategies include livelihood diversification, livestock diversification, growing perennial trees, animal fattening, growing fast maturing, and drought resistant crops (see Table 4). Ayele (2008) and Geberemhedin (2009) also indicated that the adaptive strategies against climate - related shocks include adjustments in farm management practices (improved seeds, chemical fertilizers, water harvesting, soil conservation and cultivating fast maturing plants) and diversification of crops and livelihood activities. Similarly, Deressa, Hassan, Tekie, Mahmud \& Ringler 
(2008) found out that the use of different crop varieties; tree planting, soil conservation, early and late planting and irrigation were vital adaptive strategies of the Nile Basin regions of Ethiopia.

As shown in Table 4, the major adaptive strategies among the sampled households include diversification of crops (62.2\%), diversification of livestock kept (62.5\%) and seed reserves (54.4\%) and growing of eucalyptus trees (about 54\%).

Table 4: Adaptive strategies of the sampled households by agro-ecological zones (Percentage of respondents)

\begin{tabular}{|l|l|l|l|l|}
\hline Adaptive strategies & Dega & Woina-Dega & Kolla & Total \\
\hline Diversifying crops & 79.7 & 69.6 & 57.2 & 62.2 \\
\hline Diversifying livestock & 88.6 & 72.9 & 26.1 & 62.5 \\
\hline Seed reserves & 85.7 & 64.3 & 23.1 & 54.4 \\
\hline Growing eucalyptus trees & 84.3 & 58.6 & 18.3 & 53.7 \\
\hline Fattening livestock & 55.7 & 41.4 & 31.3 & 46.1 \\
\hline Growing fast maturing plants & 82.8 & 21.4 & 24.4 & 42.9 \\
\hline Diversifying fields & 78.6 & 51.4 & 0.0 & 50.1 \\
\hline Livelihood diversification & 39.5 & 21.8 & 14.9 & 25.4 \\
\hline Water harvesting & 28.6 & 30.0 & 0.0 & 20.4 \\
\hline Saving expensive materials & 8.6 & 34.3 & 0.0 & 14.4 \\
\hline Natural resource conservation & 76.4 & 56.5 & 23.54 & 52.1 \\
\hline
\end{tabular}

Source: Field survey, March 2011

In-depth interviews with key informants revealed that adaptive strategies employed by the sampled households in the study area did not improve the availability of food and sources of income. According to them low start-up capital, high credit services, erratic weather conditions and degraded and shortage farmland limited the efficient use of adaptive strategies for better livelihoods.

Growing of apple trees and eucalyptus trees are now among the main sources of income for the Dega farm households. These types of trees can be grown in a much-degraded ecology and could be taken as the best adaptive strategies for the poor households in the study area (see Figure 2). Planting of eucalyptus trees was common in the Dega zone because of accessibility to the main road that links Bahir Dar and Mekele regional capitals. Rami (2002) argued that selling and trading eucalyptus tree is the main adaptive strategies 
along the main road that connects Gondar and Wollo over impressive mountain ridges and highland plateaus.
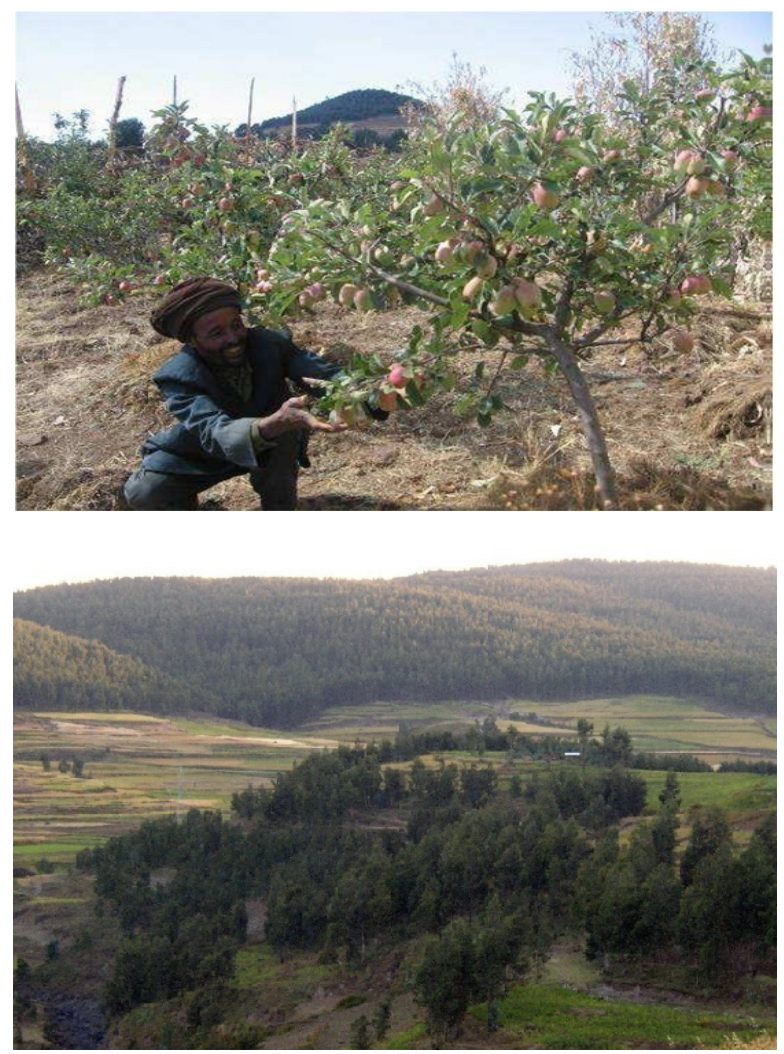

Figure 2: Highland apple (left) and Eucalyptus tree forest on the degraded and marginal lands (right)

Source: Photo taken in the field, 2011

Fattening and improved livestock in the study area is not well developed. However, as shown in Figure 3, there was a practice of rearing improved sheep in some selected kebeles in the district. 


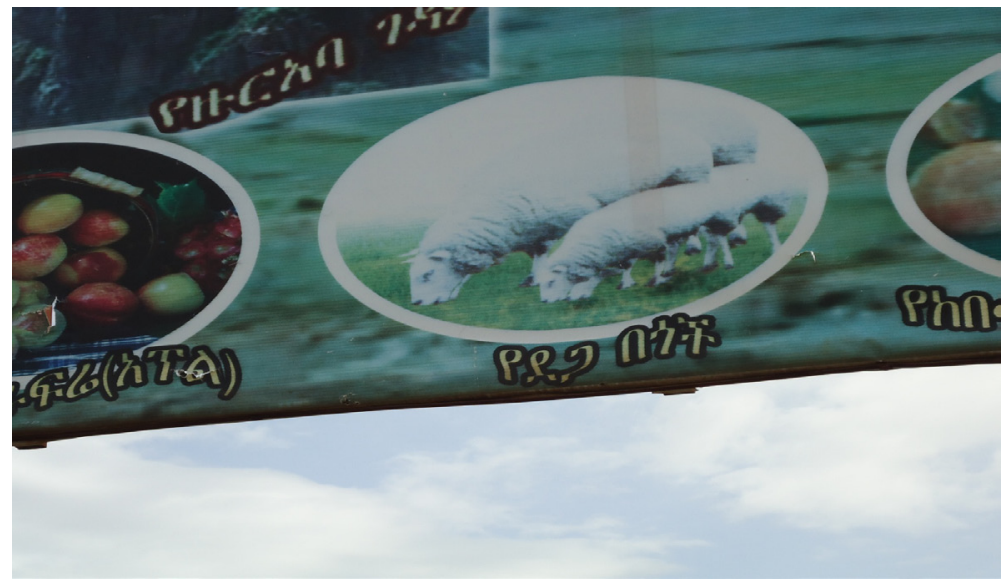

Figure 3: Rearing improved sheep in Dega agro-ecological zone

Source: Photo taken in the field, 2011

Diversification of livestock as a strategy was found dominant in the Dega and Woina-Dega agro-ecological zones of the study area (see Table 4). Soil and vegetation conservation, which is an important strategy to sink carbon emission, was also better accomplished in Dega zone. In relation to this, Nyong, Adesnia and Elasha (2007) stated that in the African Sahel, mitigation activities are traditionally employed as natural resource conservation measures, but they generally serve the dual purpose of reducing the emission of GHG from anthropogenic sources and enhancing carbon sink. Carbon sink enhancement generally involves forestry programmes that protect the forest and encourage afforestation in marginal areas including rangelands (Nyong et al., 2007). Diversifying farm plots, growing a range of crops, diversifying income sources into non/off-farm enterprises that are sensitive to climate change are adaptive measures in order of importance to climate change and drought-prone environments (Lobell \& and Burke, 2010). The green economy currently being practiced by the government of Ethiopia in a much degraded agro-ecology could be exemplary to reduce the greenhouse gas emission and to conserve the soil from rampant highland erosion.

Adaptive strategies by wealth categories showed that the better-off households practised growing of trees ( $82.5 \%)$, diversifying crops ( $79.2 \%)$, diversifying fields $(65.7 \%)$ and natural resource conservation (62.8\%) (see Table 5). The survey data showed that diversification of livestock kept was the main adaptive strategy for the better-off and the middle households. The majority of the poor (70.8\%) have grown fast maturing plants to alleviate the immediate problem of food crises. Livelihood diversification into non-farm/off-farm activities is found to be important adaptive strategies. Livelihood diversification is not only a choice, but it is mandatory in order to survive in the face of an eminent climate variability and change. Nevertheless, as shown in Table 5, livelihood diversification is 
limited because of lack of income sources, poor social network, poor infrastructure, low credit availability and high interest rate, and low value given by the local authorities. Table 5 illustrates that the better-off households, because of their enhanced capital investment are able to diversify their livelihood schemes into non-farm activities, while the poor are involved more in offering causal labor and moving to other places in search of job opportunities. Though water-harvesting technology is a vital strategy in drought-prone areas such as Lay Gayint, the survey results showed that it was the least survival strategy for all wealth categories.

Table 5: Adaptive strategies of the sampled households by wealth categories (Percentage of respondents)

\begin{tabular}{|l|l|l|l|l|}
\hline Adaptive strategies & Better - off & Middle & Poor & Total \\
\hline Diversifying crops & 79.2 & 65.6 & 44.9 & 62.2 \\
\hline Diversifying livestock & 68.6 & 68.3 & 52.1 & 62.5 \\
\hline Seed reserves & 68.5 & 55 & 40.3 & 54.4 \\
\hline Growing of saleable trees & 82.5 & 53.3 & 35.2 & 53.7 \\
\hline Fattening livestock & 61.4 & 49.7 & 27.5 & 46.1 \\
\hline Diversifying fields & 65.7 & 46.7 & 29.2 & 50.1 \\
\hline Growing fast maturing plants & 42.1 & 45.7 & 70.8 & 52.9 \\
\hline Natural resource conservation & 62.8 & 53.4 & 42.3 & 52.1 \\
\hline Livelihood diversification & 37.8 & 22.7 & 15.9 & 25.4 \\
\hline Water harvesting & 33.1 & 20.0 & 8.6 & 20.4 \\
\hline
\end{tabular}

Source: Field survey, March 2011

From the discussion, it can be concluded that the poor households in both agro-ecological zones were engaged dominantly in coping strategies for survival, while the better-off households dominantly engaged in long-term strategies. For example, petty trading, livestock fattening, livestock diversification, growing perennial trees such as eucalyptus and apple fruits are commonly employed by the better-off households in the study area. Smoothening consumption, borrowing from relatives, public works, sale of charcoal/ fuel wood, sale of cow dung, engaging in causal labor, and desperate out-migration are strategies commonly practised by the poor households in the study area.

Households were asked to state the factors affecting them in employing adaptation strategies. The majority of the households sampled indicated that low level of education $(67 \%)$, scarcity of assets $(87.6 \%)$, lack access to extension and credit services (78.9\%), rainfall variability (98\%), located in degraded and rugged ecological zones $(54.6 \%)$ and 
lack of climatic related information(34.5\%) are important factors influencing households' adaptive strategies against climate-related shocks in the study area.

\section{Water Harvesting Technology as Adaptive Strategies}

The main cause of food insecurity in the study area is unpredictable rainfall and/or shortage of water. Thus, the use of rainwater harvesting technology could partly solve water deficiency during the dry season. As shown in Table 4, the use of water-harvesting technology was absent in Kolla agro-ecological zone. However, Kolla zone is characterized by drought-prone and erratic rainfall and suffered from shortage of water during the dry season. In view of this, one key informant in Kolla zone indicated his opinion in the following ways:

In my locality, there is a serious problem of water during the dry season and on average, my wife traveled a round-trip of about four hours a day to fetch water. The problem affects my livestock. I always move my small and big ruminants to a water point about four to five hours a day and this made my livestock to collapse physically during the dry season. In my locality, the dry months were prolonged in the year 2009 and I lost two milking cows because of scarcity of water (Key Informant (KI, March 20, 2011).

In relation to this, Daniel (2007) indicated that rainwater-harvesting technology improves households' food security, help in recovering land management practices and promote intensive agriculture to improve livelihoods. In view of this, the regional government has given due attention to rainwater harvesting technology, especially in drought-prone areas to boost the livelihoods of the farm households. Though the regional government's motive was to utilize rainwater for better livelihoods, the study found out that it was inefficient, making it almost a useless attempt. The inefficient use of rainwater harvesting emanates from poor management and low awareness of the households in the proper use of the technology. As a result, more than $80 \%$ of the respondents in all agro-ecologies did not use rainwater-harvesting technologies during the field survey (see Table 4). 


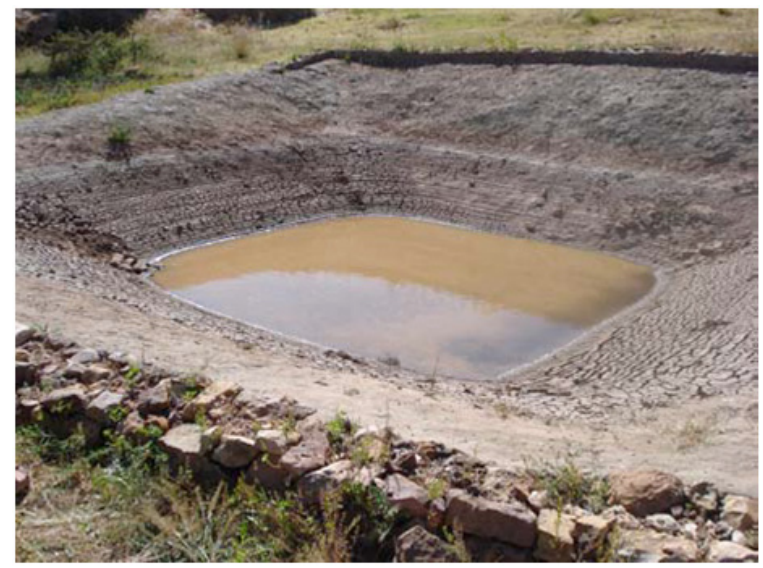

Figure 4: Water harvesting scheme constructed at household level

As observed in the field, beneficiaries were forced to construct ponds without creating awareness, consequently the few ponds constructed were not sustainable and were poor in quality. In this regard, one key informant from Woina-Dega zone shared his experience in the following ways:

The ponds constructed were not profitable. Rather they become a potential threat for my livestock, because they are not protected by fence. Besides, they cannot hold water during the dry season because of siltation and seepage problems. Moreover, they serve as a breeding ground for mosquitoes (KI, March 20, 2011).

In general, constructed in an open structure, absence of grass or vegetation cover, high evaporation rate during the dry season, high seepage and siltation problems (Figure 4); the ponds constructed in many parts of the study area were not used as adaptive strategies for the poor households. However, it is an important technology in droughtprone areas, such Lay Gayint district in improving livelihoods.

\section{Conclusions and Recommendation}

Located in the drought-prone areas of the Amhara Region, the study area is characterized by irregularity in the arrival of the first rains, inadequacy in the amount received and failure in the middle of the growing of crops. These problems are particularly severe in Woina-Dega and Kollaagro-ecological zones.

The study found out that the coping strategies employed by the households did not help to improve households' food security outcome; rather it is the major cause for environmental degradation. The implication is that the poor households who do nothave 
other options are depending on nature in producing charcoal and firewood for their livelihoods. The situation resulted in the removal of vegetation cover directly affecting the fertility of the land.

To minimize the challenges, the community in the study area is implementing soil and water conservation measures and growing of highland apples to improve livelihoods. However, the study found out that households in the study area are in precarious situations and are exposed to chronic food insecurity for many years. In the face of climate change/variability and environmental degradation, the proper use of rainwater harvesting technology is an imperative strategy that should be promoted by the local governments in collaboration with the rural communities. Hence, promoting integrated community-based natural resource management with the objective of improving soil and water resources, restoring of degraded lands have to be given high priority by the local community and the regional and local governments; that is improving food security at household level requires integrated rural development interventions aimed at improved natural resources management practices and diversification of livelihood strategies. In general, geographically differentiated and socially relevant development interventions need to be designed by the government and local community to improve food security in the study area and in other similar environments in the country.

\section{References}

Aklilu, T., Yigzaw, D. and Tilahun, T. (2000). Farming systems in Lay Gayint district: Constraints and possible research and development intervention. Adet Agricultural Research Centre, Bahir Dar, Ethiopia.

Ayele, T. (2008). Livelihood adaptation, risks and vulnerability in rural wolaita, Ethiopia. Doctoral thesis presented to the department of international environment and development, studies Noragric, Norwegian University of Life Sciences Oslo.

Degefa, T. (2005). Rural livelihoods, poverty and food insecurity in Ethiopia: A case study of Ernessa and Garbi communities in Oromiya Zone. Amhara National Regional State. Published doctoral thesis Norwegian University of Science and Technology, NTNU.

Deressa, T., Hassan, R., Tekie, A., Mahmud, Y. and Ringler, C. (2008). Analyzing the determinants of farmers' choice of adaptation methods and perceptions of climate change in the Nile Basin of Ethiopia. Environment and production technology division, IFPRI discussion paper oo798.

Devereux, S., Sabates, W., Tefera, M. and Taye, H. (2006). Ethiopia's PSNP programme: Trends in PSNP transfers within targeted households. Final report, Ids and Indak International, Addis Ababa. 
Dietz, T. and Von Der Geest, K. (2004). A Literature survey about risk and vulnerability in dry lands, with a focus on the Sahel. In Dietz et al. (Eds.) The Impact of climate change on dry lands with focus on West Africa. Netherlands: Kluwer Academic Publishers.

Ellis, F. (2000). Rural livelihoods and diversity in developing countries. Oxford: Oxford University Press.

Ellis, F. (2003).Human vulnerability and food insecurity: policy implication. Overseas Development Group, London, U.K.

Gebermedhin, D. (2009). Small water harvesting: Its contribution towards food security under the prevailing impact of climate change in Amahara Region Ethiopia. Presented at McGill conference on global food security, McGill University.

Guinand, Y. (2001). Towards integrated food security through subsidized employment and income generation activities: Aspects and realities of chronic food insecure areas along Tekeze River and in the Semien Mountains. United Nation Development Programme, United Nations Emergency Unit in Ethiopia (UNDP-EUE).

Heijmens, A. (2001). Vulnerability: Another of perception. Benfield Grighazard Research Centre University College of London.

Hoddinott, J. (1999). Choosing outcome indicators of household food security. International Food Policy Research Institute, Washington D.C.

Lobell, D. and Burke, M. (2010). Food security and adaptation to climate change: What do we know? In Lobell and Burke (Eds.) Proceedings on climate change and food security, pp. 133-153, Stanford University, USA.

Maharjam, K. L. and Chhetri, A. K. (2006). Food insecurity and coping strategies in rural areas of Nepal: A case study of Dailkh in Mid-Western Development Region. Journal of International Development and Cooperation, 12 (20), pp. 25-45.

Markos, E. (1997). Demographic responses to ecological degradation and food insecurity: Drought-prone areas in northern Ethiopia. Published Doctoral Thesis, University of Amsterdam, Netherlands.

Maxwell, D. (2008). The coping strategy index: A tool for rapid measurement of household foods and the impact of food aid programmes in humanitarian agencies. Field Method Manual, Second Edition, TANGO, USAID, WFP and CARE.

Nyong, A., Adesnia, F. and Elasha, B. (2007). The value of indigenous knowledge in climate change mitigation and adaptive strategies in the African Sahel. Mitigation Adaptation Strategy Global Change, 12, pp. 787-797.

Patrice, C. (1993). Famine household coping strategies: Their usefulness for understanding household response to armed conflict. RSP Documentation Centre. 
Qureshi, s. H. (2007). Creating an index to measure food security: Identifying the components and determinants and testing usefulness. Heller School for Social Policy and Management. Brandeis University, USA.

Rami, H. (2002). Food aid is not development. United Nations Emergency Unit in Ethiopia (UN-EUE).

Silvestri, S., Bryan, E., Ringler, C., Herrero, M. and Okoba, B. (2012). Climate change perception and adaptation of agro-pastoral communities in Kenya. Regional Environment Change, 12, pp. 791-802.

Smit, B. and Wandel, J. (2006). Adaptation, adaptive capacity and vulnerability. Global Environmental Change, 16, pp. 282-292.

Webb, P. and Von Barun, J. (1994). Famine and food security in Ethiopia: Lessons from Africa. John Wiley and Sons, New York.

Wisner, B., Blaikie, P., Cannon, T. and Davis, I. (2003). At risk: Natural hazards, people's vulnerability and disasters. ( $2^{\text {nd }}$ ed.). Rutledge Inc.

Wondwosen, M. (2011). Underlying causes of rural household food insecurity and coping mechanisms in Tenta Woreda in South Wollo Zone Amhara Region. Unpublished Master Thesis, Bahir Dar University, Ethiopia. 